\title{
The Role of Adenomyosis in the Pathogenesis of Preeclampsia
}

\author{
Die Rolle der Adenomyose in der Pathogenese der Präeklampsie
}

Authors

Affiliations
P. S. Hasdemir ${ }^{1}$, M. Farasat ${ }^{2}$, C. Aydin ${ }^{1}$, B. C. Ozyurt ${ }^{3}$, T. Guvenal ${ }^{1}$, G. Pekindil ${ }^{2}$

${ }^{1}$ Department of Obstetrics and Gynecology, Celal Bayar University Medical School, Manisa, Turkey

${ }^{2}$ Department of Radiology, Celal Bayar University Medical School, Manisa, Turkey

${ }^{3}$ Department of Public Health, Celal Bayar University Medical School, Manisa, Turkey

\author{
Key words \\ - adenomyosis \\ - fetal growth restriction \\ - magnetic resonance imaging \\ - preeclampsia \\ - junctional zone \\ Schlüsselwörter \\ - Adenomyose \\ - fetale Wachstums- \\ retardierung \\ - Magnetresonanztomografie \\ - Präeklampsie \\ - Übergangszone
}

\section{Abstract \\ $\nabla$}

Introduction: Adenomyosis can cause defective deep placentation. Preeclampsia is known to be associated with abnormal placentation. The aim of this study was to compare the presence of adenomyosis on magnetic resonance imaging in patients with and without history of preeclampsia in order to investigate the possible role of adenomyosis in the pathogenesis of preeclampsia.

Materials and Methods: This prospective, randomized study consisted of patients with $(n=35)$ and without $(\mathrm{n}=34)$ history of preeclampsia. Direct (submucosal microcysts, adenomyoma and cystic adenomyoma) and indirect (maximal thickness of junctional zone, ratio of maximal thickness of junctional zone to myometrial thickness, junctional zone differential, focal thickening of junctional zone, globally enlarged uterus and non-uniform junctional zone contours) signs of adenomyosis were assessed by pelvic magnetic resonance imaging.

Results: The prevalence of adenomyosis was found to be more common in patients with preeclampsia und fetal growth restriction compared to patients without fetal growth restriction (94.4 vs. $64.7 \% ; p=0.041$ ), respectively. There was a strong association between maximal thickness of junctional zone ( 9 vs. $13 \mathrm{~mm}, \mathrm{p}=0.005$ ), ratio of maximal thickness of junctional zone to myometrial thickness ( 0.42 vs. $0.66, p=0.001)$ and junctional zone differential ( 3 vs. $5 \mathrm{~mm}, \mathrm{p}=0.02$ ) and lateonset preeclampsia.

Conclusions: Presence of adenomyoma is more common in patients with preeclampsia complicated with fetal growth restriction. Indirect signs of adenomyosis detected on pelvic magnetic resonance imaging might have a role in the pathogenesis of late-onset preeclampsia.

\section{Zusammenfassung \\ $\nabla$}

Einleitung: Die Adenomyose kann zu Einnistungsstörungen der Plazenta führen. Es ist bekannt, dass die Präeklampsie auf einer abnormen Plazentation beruht. Das Ziel dieser Studie bestand darin, die Adenomyose in Patientinnen mit und ohne Vorgeschichte der Präeklampsie mittels bildgebender Verfahren zu vergleichen, um die etwaige Rolle der Adenomyose bei der Pathogenese von Präeklampsie zu evaluieren.

Material und Methoden: Es wurden Patientinnen mit $(n=35)$ oder ohne $(n=34)$ Vorgeschichte der Präeklampsie in diese prospektive, randomisierte Studie aufgenommen. Bei allen Patientinnen wurde eine Magnetresonanztomografie des Beckens durchgeführt, zur Beurteilung der direkten (submuköse Mikrozysten, Adenomyome und zystische Adenomyome) und indirekten (maximale Dicke der Übergangszone, Verhältnis zwischen der maximalen Dicke der Übergangszone und der Dicke des Myometriums, Differenzial der Übergangszone, fokale Verbreiterung der Übergangszone, diffus vergrößerter Uterus und irreguläre Kontur der Übergangszone) Anzeichen der Adenomyose.

Ergebnisse: Die Adenomyose kam häufiger bei Patientinnen mit Präeklampsie und fetaler Wachstumsretardierung vor, verglichen mit Patientinnen ohne fetale Wachstumsretardierung (94,4 vs. 64,7\%; $p=0,041)$. Es bestand eine enge Verbindung zwischen der maximalen Dicke der Übergangszone ( 9 vs. 13 mm, p = 0,005), dem Verhältnis zwischen der maximalen Dicke der Übergangszone und der Dicke des Myometriums (0,42 vs. $0,66, p=0,001)$, dem Differenzial der Übergangszone ( 3 vs. 5 mm, p = 0,02) und der spät einsetzenden Präeklampsie.

Schlussfolgerung: Die Adenomyose kommt häufiger bei Patientinnen mit Präeklampsie und fetaler Wachstumsretardierung vor. Indirekte Anzeichen der Adenomyose, die bei einer Magnet- 
resonanztomografie des Beckens festgestellt werden, könnten eine Rolle bei der Pathogenese von spät einsetzender Präeklampsie spielen.

\section{Introduction}

Adenomyosis is a benign invasion of endometrial glands and stroma into the myometrium surrounded by a hypertrophic and hyperplastic myometrial tissue and represents a spectrum of lesions, ranging from increased thickness of the junctional zone (JZ) to overt adenomyosis and adenomyomas [1,2]. The use of modern imaging techniques, especially magnetic resonance imaging (MRI), enables its identification as diffuse or focal thickening of the myometrial JZ and less common forms of adenomyosis such as adenomyoma, adenomyomatous polyps, and cystic adenomyoma have also been described [3].

During pregnancy, trophoblast invasion to the endometrium and the myometrial JZ causes decidualization and unique vascular changes [4]. Defective deep placentation was reported to be associated with a spectrum of obstetrical complications such as late miscarriage, preterm labour, fetal growth restriction (FGR) and preeclampsia [5].

Preeclampsia is defined as new hypertension and substantial proteinuria at or after 20 weeks of gestation [6]. Although the cause of preeclampsia remains largely unknown, the leading hypotheses strongly rely on disturbed placental function in early pregnancy [7]. Failure of placentation, particularly the physiological transformation of spiral arteries, leads to a stressed, unperfused placenta. Most probably because of the similar pathogenesis, preeclampsia could be seen together with FGR, stillbirth, placental abruption and preterm labor [8].

To the best of our knowledge, there is no prior clinical study investigating the relationship between adenomyosis and preeclampsia. The aim of this study was to compare the presence of adenomyosis on magnetic resonance imaging in patients with and without history of preeclampsia in order to investigate the possible role of adenomyosis in the pathogenesis of preeclampsia.

\section{Material and Methods}

$\nabla$

This study was a prospective, randomized study conducted at an Obstetrics and Gynecology Clinic of a University Hospital in Turkey, between January and July 2015.

A total of 69 women were included in the study. All patients $(\mathrm{n}=76)$ with diagnosis of preeclampsia who were delivered at our obstetrics clinic during study period were called by phone and asked for enrollment in the study. Among this group, a total of 35 patients agreed with MRI examination and were enrolled. The control group consisted of 34 patients having presented with non-gynecologic complaint with a history of at least one pregnancy without preeclampsia and without any history of infertility, endometriosis and/or leiomyoma, uterine surgery except prior low transverse incision cesarean section and history of hydatiform mole. The control group was randomized based on age, gravidity and parity numbers by computer.

All study subjects underwent pelvic MRI examination at least 6 months after their pregnancy during out of their menstrual phase $[9,10]$. The primary outcome was the presence of adenomyosis. The secondary outcomes were early or late onset of preeclampsia, FGR and preeclampsia-related complications (abrupt- io placenta, HELLP syndrome and eclampsia) in the presence of adenomyosis.

Full medical histories were obtained. Preeclampsia was defined as hypertension with a systolic blood pressure of $140 \mathrm{mmHg}$ or higher or a diastolic blood pressure of $90 \mathrm{mmHg}$ or higher occurring after 20 weeks of gestation in a woman with previously normal blood pressure and proteinuria of at least $300 \mathrm{mg} / 24$ hour urine collection [6]. Proteinuria in spot urine sample instead of 24 hour urine collection was used for diagnostic purposes in patients having undergone emergency delivery. The onsets of preeclampsia were considered as early (<34 gestational weeks) or late ( $\geq 34$ gestational weeks). FGR was defined as at least 2 weeks of retardation in ultrasonographic measures of the fetus compared to expected gestational week. All clinical assessments of the participants were performed by the same investigator ( $\mathrm{PSH}$ ), and all MRI evaluations were assessed by the same experienced radiologist (MF). The radiologist was blind for the study groups.

\section{MRI assessment}

MRI was performed with 1.5-Tesla scanners (Signa, General Electric Medical Systems). We acquired 7-mm slices with 1-mm spacing in the sagittal, coronal, and axial planes relative to the orientation of the uterine cavity, using T2-weighted fast (turbo) spin echo sequences (TR/TEef, 3500-4000 ms/100 ms, echo train length 17) in all three planes. Surface coils (phase array pelvic coils) were used for data acquisition and examinations were completed within 30 minutes in each case.

Previously described MRI criteria for the diagnosis of adenomyosis were used $[9,11]$. Both direct and indirect signs of adenomyosis on MRI were measured. Submucosal microcysts, adenomyoma and cystic adenomyoma were considered as direct signs. Maximum thickness of JZ ( $\geq 12 \mathrm{~mm}$ ), JZ differential (the highest value calculated as $\mathrm{JZ}_{\max }$ minus $\mathrm{JZ}_{\text {min }}$ measured in both anterior and posterior walls in the sagittal slices) $(>5 \mathrm{~mm})$, the ratio of $\mathrm{JZ}_{\max }$ thickness to myometrial thickness from the same plane ( $>40 \%$ ), focal thickenning of JZ, globally enlarged uterus and non-uniform JZ contours were considered as indirect signs of adenomyosis. Presence of adenomyosis was defined as presence of at least one direct and/or indirect signs on MRI ( $\bullet$ Fig. 1).

\section{Ethical consent}

The research protocol was approved by the institutional review board (no. 20478486-22) on January 14th, 2015. Informed consent was obtained from each participant.

\section{Statistical analysis}

Statistical analysis was performed with IBM SPSS Statistics 21.0 (SPSS Inc., Chicago, IL). The Shapiro-Wilk test was used to calculate whether the numeric variables were normally distributed. For normally distributed variables, numeric data were analyzed with the Student's t test and cross-tables and Pearson $\mathrm{X}^{2}$ analysis were employed in the evaluation of the categorical data. The Mann-Whitney U test was used for abnormally distributed variables. Fisher's exact test was used in data with small sample size with an expected frequency of $5 \%$ or less. P-value $<0.05$ was considered as statistically significant. 


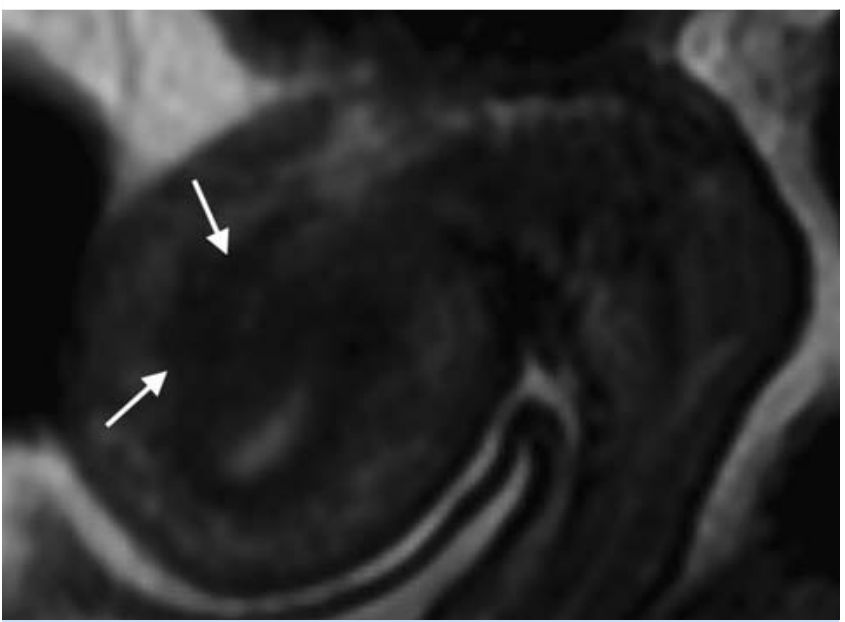

Fig. 1 Pelvic MRI at mid-sagittal plane showing (arrows) increased focal junctional zone thickness.
Thirty-three patients in each group had a power of 0.80 with the effect size of $d=0.70$ and $\alpha=0.05$ based on sample size calculations.

\section{Results}

\section{Description of the sample}

Study population consisted of 69 patients (median age 29 years old, range 17-41). Baseline demographic and clinical characteristics in patients with and without preeclampsia were similar except for the older gestational age at delivery in control group most likely due to larger proportion of uncomplicated pregnancies ( $\bullet$ Table 1$)$.

Mean age, number of gravidity and parity rates of patients with and without FGR were similar $(28.77 \pm 5.52$ vs. $28.84 \pm 5.42$, $\mathrm{p}=0.772 ; \quad 2 \pm 1.37$ vs. $2.21 \pm 1.49, \mathrm{p}=0.646 ; 1.55 \pm 0.85$ vs. $1.57 \pm 0.94, p=0.983$ ), respectively. Mean age, number of gravidity and parity rates of patients with early and late onset preeclampsia were similar $(26.27 \pm 4.31$ vs. $29.76 \pm 6.75, p=0.068$; $1.77 \pm 1.16$ vs. $2.29 \pm 1.86, \mathrm{p}=0.562 ; 1.27 \pm 0.75$ vs. $1.70 \pm 0.92$, $\mathrm{p}=0.105)$, respectively.

In patients with preeclampsia, the rate of HELLP syndrome, abruptio placenta and eclampsia were $45.7,14.3$ and $8.6 \%$, respectively.

\section{Comparison of adenomyosis and preeclampsia, its related complications and FGR}

Adenomyosis was present in $85.5 \%$ of the study population. The prevalence of adenomyosis was not different between patients with and without preeclampsia ( 88.6 vs. $82.4 \%, \mathrm{p}=0.513$ ), respectively ( Table 2). The JZ differential tended to be higher in patients with preeclampsia compared to control subjects (4.14 \pm 2.54 vs. $3.11 \pm 1.96 ; p=0.066$ ), respectively ( $\bullet$ Table 2 ).

There was no relationship between the presence of adenomyosis and preeclampsia-related complications including abruptio placenta $(\mathrm{p}=0.477)$, HELLP syndrome $(\mathrm{p}=1.000)$ and eclampsia $(p=0.313)$. Presence of adenomyosis were compared in patients with preeclampsia with or without FGR and only the presence of
Table 1 Baseline demographic and clinical characteristic of the preeclampsia and control groups.

\begin{tabular}{|c|c|c|c|}
\hline & $\begin{array}{l}\text { Preeclampsia } \\
\text { group }(n=35)\end{array}$ & $\begin{array}{l}\text { Control } \\
\text { group } \\
(n=34)\end{array}$ & p-value \\
\hline Age & $27.97 \pm 5.81$ & $30.17 \pm 4.92$ & $0.094^{*}$ \\
\hline Smoking & $12 \%$ & $26 \%$ & $0.138^{* *}$ \\
\hline Gravidity & $2.02 \pm 1.54$ & $2.20 \pm 1.14$ & $0.591^{*}$ \\
\hline Parity & $1.48 \pm 0.85$ & $1.76 \pm 0.95$ & $0.205^{*}$ \\
\hline Abortion & $0.54 \pm 1.06$ & $0.47 \pm 0.89$ & $0.762^{*}$ \\
\hline $\begin{array}{l}\text { Gestational age at } \\
\text { delivery }\end{array}$ & $33.75 \pm 4.26$ & $36.73 \pm 2.95$ & $0.001^{*}$ \\
\hline $\begin{array}{l}\text { Time interval (delivery } \\
\text { to MRI) }\end{array}$ & $12.25 \pm 3.48$ & $13.26 \pm 3.06$ & $0.207^{*}$ \\
\hline DM and/or GDM & $15 \%$ & $3 \%$ & $0.197^{* * *}$ \\
\hline Presence of myoma & $17.1 \%$ & $5.9 \%$ & $0.259 * * *$ \\
\hline $\begin{array}{l}\text { Presence of endome- } \\
\text { triosis/endometrioma }\end{array}$ & $2.9 \%$ & $8.8 \%$ & $0.356^{* * *}$ \\
\hline
\end{tabular}

DM: diabetes mellitus, GDM: gestational diabetes mellitus, MRI: magnetic resonance imaging

${ }^{*}$ student's t-test, ${ }^{* *} \mathrm{X}^{2}$ test, ${ }^{* * *}$ Fisher's exact test

adenomyoma was more common in patients with FGR compared to patients without FGR (94.4 vs. 64.7\%; p =0.041), respectively ( Table 3). There was no correlation between FGR and early/late onset preeclampsia; 9 out of of 18 patients with FGR (50\%) had pregnancy complicated with early-onset preeclampsia while 9 out of 18 patients with FGR were complicated with late-onset preeclampsia $(\mathrm{p}=0.862)$.

\section{Subgroup analysis based on the early or late onset of preeclampsia}

Diagnostic signs (direct and indirect) of adenomyosis were compared in patients with early and late onset preeclampsia. There was a strong association between three indirect signs of adenomyosis and late-onset preeclampsia; $\mathrm{JZ}_{\max }$ /myometrial thickness, $\mathrm{JZ}$ differential and $\mathrm{J} \mathrm{Z}_{\max }$ were found to be significantly higher in patients with late-onset preeclampsia than in patients with early-onset preeclampsia [0.42 (0.21-0.72) vs. $0.66(0.36-0.83)$, $\mathrm{p}=0.001 ; 3$ (1-6) vs. 5 (2-13), p=0.020; 9 (4-15) vs. 13 (7-19), $\mathrm{p}=0.005$ ], respectively ( $\square$ Table 4$)$.

\section{Discussion}

$\nabla$

MRI is currently an important technique with high diagnostic value for the diagnosis of adenomyosis [12]. Histopathologic evaluation of uterus has been the gold standard diagnostic method for adenomyosis until Hricak et al. described the normal zonal anatomy as a distinct low signal on T2-weighted sequences seperating endometrium in high signal intensity from outer myometrium in intermediate signal on MRI in 1983 [13].

Adenomyosis is not a uniform disease. It rather represents a spectrum of lesions, ranging from disruption of the $\mathrm{JZ}$ architecture with little or no endometrial invasion to overt diffuse adenomyosis and focal adenomyomas [4]. JZ is the inner $1 / 3$ part of myometrium and found to be different than outer myometrium by its embryonic origin and functions [4,14]. Although the distinct myometrial zonal anatomy on MRI disappears in pregnancy, disruption of the JZ prior to conception may have profound repercussion on deep placentation and subsequent pregnancy outcome. 
Table 2 Comparison of MRI findings based on adenomyosis characteristics in preeclampsia and control groups.

\begin{tabular}{|c|c|c|c|}
\hline & $\begin{array}{l}\text { Preeclampsia } \\
\text { group }(n=35)\end{array}$ & $\begin{array}{l}\text { Control } \\
\text { group } \\
(n=34)\end{array}$ & p-value \\
\hline Submucosal microcyst & $0 \%$ & $2.9 \%$ & $0.490 * * *$ \\
\hline Cystic adenomyoma & $2.9 \%$ & $2.9 \%$ & $1.000 * * *$ \\
\hline $\begin{array}{l}\text { Presence of } \\
\text { adenomyoma }\end{array}$ & $80 \%$ & $70.6 \%$ & $0.364^{* *}$ \\
\hline $\begin{array}{l}\text { Adenomyoma max } \\
(\mathrm{mm})\end{array}$ & $5.20 \pm 4.22$ & $4.94 \pm 4.24$ & $0.800^{*}$ \\
\hline Adenomyoma location & $\%$ & $\%$ & $0.177^{* *}$ \\
\hline Anterior & 28.6 & 8.7 & \\
\hline - Posterior & 25 & 13 & \\
\hline Fundal & 17.9 & 39.1 & \\
\hline - Posterior-fundal & 7.1 & 4.3 & \\
\hline - Anterior-fundal & 7.1 & 26.1 & \\
\hline Anterior-posterior & 7.1 & 4.3 & \\
\hline $\begin{array}{l}\text { Anterior-posterior- } \\
\text { fundal }\end{array}$ & 7.1 & 4.3 & \\
\hline $\begin{array}{l}\text { Total size of adeno- } \\
\text { myoma (mm) }\end{array}$ & $11.82 \pm 12.32$ & $12.12 \pm 7.82$ & $0.918^{*}$ \\
\hline Focal JZ $\left(J Z_{\max }\right)(\mathrm{mm})$ & $10.40 \pm 3.98$ & $11.32 \pm 3.99$ & $0.340^{*}$ \\
\hline Localization of $\mathrm{J} \mathrm{Z}_{\max }$ & $\%$ & $\%$ & $0.208^{* *}$ \\
\hline - Anterior & 21.7 & 29.2 & \\
\hline - Posterior & 52.2 & 16.7 & \\
\hline - Fundal & 8.7 & 8.3 & \\
\hline - Fundal-posterior & 0 & 7.2 & \\
\hline Fundal-anterior & 4.3 & 8.3 & \\
\hline Anterior-posterior & 8.7 & 29.2 & \\
\hline $\begin{array}{l}\text { Anterior-posterior- } \\
\text { fundal }\end{array}$ & 4.3 & 4.2 & \\
\hline $\mathrm{J} \mathrm{Z}_{\text {max }} /$ myometrium & $0.53 \pm 1.18$ & $0.55 \pm 0.13$ & $0.726^{*}$ \\
\hline JZ differential (mm) & $4.14 \pm 2.54$ & $3.11 \pm 1.96$ & $0.066^{*}$ \\
\hline J not-uniform & $51.4 \%$ & $52.9 \%$ & $0.900^{* *}$ \\
\hline Uterine size (mm) & $47.48 \pm 7.83$ & $50.33 \pm 7.62$ & $0.130^{*}$ \\
\hline $\begin{array}{l}\text { Adenomyosis } \\
\text { diagnostic criteria }\end{array}$ & $\%$ & $\%$ & $0.239^{* *}$ \\
\hline Absent & 11.4 & 17.6 & \\
\hline Indirect & 34.3 & 20.6 & \\
\hline Direct & 11.4 & 2.9 & \\
\hline $\begin{array}{l}\text { Presence of overall } \\
\text { adenomyosis }\end{array}$ & $88.6 \%$ & $82.4 \%$ & $0.513^{* * *}$ \\
\hline
\end{tabular}

${ }^{*}$ student's t-test, ${ }^{* *} \mathrm{x}^{2}$ test, ${ }^{* * *}$ Fisher's exact test, max: maximal, mm: milimeters

Thickening and disruption of the JZ appearance is strongly associated with uterine adenomyosis [4].

The placental bed, the area of the uterus underlying the placenta, plays a key role in supporting placental function by supplying oxygenated blood to the intervillous space via the spiral arteries $[15,16]$. Decidualization initiates some morphologic changes in JZ spiral arteries outside the placental bed [17]. Defective deep placentation was reported to be associated with a spectrum of obstetrical complications such as late miscarriage, preterm labour, fetal growth restriction and preeclampsia [5]. Interstitial trophoblast invasion of the JZ appears adequate, although impaired decidualization of the myometrial spiral arteries predisposes for failed intravascular trophoblast invasion in those conditions $[18,19]$.

Although the cause of preeclampsia remains largely unknown, failured remodeling of the spiral artery has especially been considered as an early defect causing preeclampsia. This abnormal
Table 3 Comparison of MRI findings based on adenomyosis characteristics in patients with preeclampsia with and without fetal growth restriction.

\begin{tabular}{|c|c|c|c|}
\hline $\begin{array}{l}\text { Adenomyosis } \\
\text { characteristics }\end{array}$ & $\begin{array}{l}\text { FGR (+) (\%) } \\
(n=18) \\
(\text { median } \\
{[\text { min-max]) }}\end{array}$ & $\begin{array}{l}\text { FGR }(-)(\%) \\
(n=17) \\
(\text { median } \\
{[\text { min-max]) }}\end{array}$ & p-value \\
\hline $\begin{array}{l}\text { Presence of } \\
\text { adenomyoma }\end{array}$ & $94.4 \%$ & $64.7 \%$ & $0.041^{* *}$ \\
\hline $\begin{array}{l}\text { Adenomyoma max } \\
(\mathrm{mm})\end{array}$ & $5.5(0-20)$ & $3(0-11)$ & $0.115^{*}$ \\
\hline $\begin{array}{l}\text { Total size of adeno- } \\
\text { myoma }(\mathrm{mm})\end{array}$ & $8(3-54)$ & $6(2-35)$ & $0.273^{*}$ \\
\hline $\mathrm{J} \mathrm{Z}_{\max } /$ myometrium & $\begin{array}{l}0.47 \\
(0.21-0.83)\end{array}$ & $\begin{array}{l}0.54 \\
(0.22-0.83)\end{array}$ & $0.175^{*}$ \\
\hline JZ differential (mm) & $3(1-9)$ & $3(2-13)$ & $0.366^{*}$ \\
\hline J non-uniform & $66.7 \%$ & $50 \%$ & $0.241^{* * *}$ \\
\hline Focal JZ $\left(J Z_{\text {max }}\right)(\mathrm{mm})$ & $10(4-18)$ & $10(4-19)$ & $0.295^{*}$ \\
\hline Uterine size $(\mathrm{mm})$ & $47.75(37-73)$ & $44(35.5-61)$ & $0.590^{*}$ \\
\hline
\end{tabular}

FGR: fetal growth restriction, JZ: Junctional Zone, max: maximal, mm: milimeters. ${ }^{*}$ Mann-Whitney $\mathrm{U}$ test, ${ }^{* *}$ Fisher's exact test, ${ }^{* * *} \mathrm{X}^{2}$ test.

Table 4 Comparison of MRI findings based on adenomyosis characteristics in patients with early and late-onset preeclampsia.

\begin{tabular}{|c|c|c|c|}
\hline $\begin{array}{l}\text { Adenomyosis } \\
\text { characteristics }\end{array}$ & $\begin{array}{l}<34 \text { weeks } \\
(n=18) \\
(\text { median } \\
{[\text { min-max]) }}\end{array}$ & $\begin{array}{l}\geq 34 \text { weeks } \\
(n=17) \\
\text { (median } \\
{[\text { min-max]) }}\end{array}$ & p-value \\
\hline $\begin{array}{l}\text { Presence of } \\
\text { adenomyoma }\end{array}$ & $72.2 \%$ & $88.2 \%$ & $0.402^{* *}$ \\
\hline $\begin{array}{l}\text { Adenomyoma max } \\
(\mathrm{mm})\end{array}$ & $4(0-11)$ & $6(0-20)$ & $0.175^{*}$ \\
\hline $\begin{array}{l}\text { Total size of adeno- } \\
\text { myoma (mm) }\end{array}$ & $7(2-27)$ & $9(2-54)$ & $0.262^{*}$ \\
\hline $\mathrm{J} \mathrm{Z}_{\max } /$ myometrium & $\begin{array}{l}0.42 \\
(0.21-0.72)\end{array}$ & $\begin{array}{l}0.66 \\
(0.36-0.83)\end{array}$ & $0.001^{*}$ \\
\hline JZ differential $(\mathrm{mm})$ & $3(1-6)$ & $5(2-13)$ & $0.020^{*}$ \\
\hline JZnon-uniform & $38.9 \%$ & $64.7 \%$ & $0.127^{* * *}$ \\
\hline Focal JZ $\left(J Z_{\max }\right)(\mathrm{mm})$ & $9(4-15)$ & $13(7-19)$ & $0.005^{*}$ \\
\hline Uterine size $(\mathrm{mm})$ & $\begin{array}{l}45.25 \\
(38.5-61)\end{array}$ & $\begin{array}{l}49 \\
(35.5-73)\end{array}$ & $0.107^{*}$ \\
\hline
\end{tabular}

JZ: Junctional Zone, max: maximal, mm: milimeters

* Mann-Whitney $\mathrm{U}$ test, ${ }^{* *}$ Fisher's exact test, ${ }^{* * *} \mathrm{X}^{2}$ test

placentation leads to reduced uteroplacental arterial flow and episodes of irregular placental perfusion resulting in oxidative stress, subsequent apoptotic and necrotic disruption of syncytial architecture and release of various components from the intervillous space into the maternal circulation, stimulating production of inflammatory cytokines. This leads to systemic maternal disease as the second stage of preeclampsia [20].

Preeclampsia consists of many different clinical subtypes like early-onset preeclampsia often complicated by FGR, preeclampsia accompanied with HELLP syndrome and late-onset preeclampsia. Early and late-onset preeclampsia are defined as preeclampsia that develops before and at or after 34 weeks of gestation, respectively. Although the presenting features overlap, they are associated with different maternal and fetal outcomes, biochemical markers, heritability, and clinical features [21]. Early onset preeclampsia has a worse prognosis characterized with early birth, perinatal death and/or severe neonatal morbidity. 
Lisonkova et al. reported that congenital anomalies were more strongly associated with early-onset disease, suggesting the presence of associated placental abnormalities that affect perfusion. In contrast, a stronger positive association between diabetes mellitus and late-onset preeclampsia suggests that relative placental insufficiency is more likely to occur in diabetic pregnancies with a larger fetus. They also observed a strong association between early-onset disease and small-for-gestational age fetuses, likely because of the profound effects of poor placental perfusion early in gestation [22]. We found a relationship between late-onset preeclampsia and indirect signs of adenomyosis on MRI suggesting that adenomyosis might be related with a relative placental insufficiency.

Although the causes of preeclampsia remain one of the great medical mysteries of our time, some promising researches are being published recently. Fisher et al. reported that cytotrophoblasts that are isolated from the placentas of affected pregnancies normalized their gene expression over 48 hours in vitro; this unexpected finding suggests that some aspects of the aberrant differentiation of cytotrophoblasts within the uterine wall that is observed in situ may be reversible. This result points to the importance of environment factors in driving the phenotype. The next challenge is to identify what they are. There are new clues to the longstanding mystery of the reason of abnormal placentation in preeclampsia and the added urgency to find the answers, because these pathways could be valuable therapeutic targets for reversing abnormal placental function in patients [23]. In light of our study, we speculate that adenomyosis (especially defective junctional zone) might be one of these mysterious factors. Thus, careful assessment for defective junctional zone during routine ultrasonographic examinations in pregnancy as a predictive factor for late-onset preeclampsia should be made.

A recent retrospective study investigated the relationship between adenomyosis and uterine enlargement and poor pregnancy outcomes on 36 cases with adenomyosis and 144 control pregnancies. They found that the adenomyosis group had significantly higher rates of preterm delivery, preterm premature rupture of membranes, small-for-gestational age, fetal malpresentation and higher cesarean delivery as compared with the control group. The authors concluded that adenomyosis was associated with a higher preterm delivery rate and more frequent occurrences of FGR and fetal malpresentation. There were no statistical differences in terms of preeclampsia between groups [24]. Similarly, we could not find any relationship between preeclampsia and overall frequency of adenomyosis. This was probably due to the fact that neither preeclampsia in itself is not a uniform diease nor adenomyosis has only one diagnostic sign [25]. We believe that subgroup analyses in larger group of patients are important to make a comment in this point of view.

Yorifuji et al. reported two pregnant cases with non-contrast magnetic resonance angiography technique. Both of the cases had large adenomyomas at the posterior site of the uteruses and both pregnancies resulted in FGR. One of the cases had preeclampsia. They speculated that "vascular steal" by adenomyosis might be the reason for the FGR in the cases [26]. We also found a relationship between the presence of adenomyoma on MRI and FGR, suggesting that presence of adenomyoma might be related with a poor placental perfusion. We found no relationship between signs of adenomyosis on MRI and development of preeclampsia-related complications such as placental abruption and eclampsia.
There are two important results of our study. Firstly, there was no overall relationship between preeclampsia and adenomyosis. Comparison of patients with late and early-onset preeclampsia and MRI characteristics showed a significant relationship between late-onset preeclampsia and indirect signs of adenomyosis. Secondly, we found a significant relationship between presence of adenomyoma and FGR. Thus, not only the mere presence of adenomyosis, but also the type and/or size of the adenomyotic lesions might have a role in the development of preeclampsia and FGR. As a limitation of our study, there was no control group of SGA without preeclampsia and numbers of the patients in subgroups were relatively small.

\section{Conclusion}

$\nabla$

Presence of adenomyoma on MRI is more common in cases with preeclampsia complicated with FGR and indirect signs of adenomyosis detected on MRI might play a role in the pathogenesis of late-onset preeclampsia. Further studies with larger groups of patients are needed to confirm these findings.

\section{Conflict of Interest}

$\nabla$

The authors declare that they have no competing interests.

\section{References}

1 Benagiano G, Brosens I. History of adenomyosis. Best Pract Res Clin Obstet Gynaecol 2006; 20: 449-463

2 Gordts S, Brosens JJ, Fusi L et al. Uterine adenomyosis: a need for uniform terminology and consensus classification. Reprod Biomed Online 2008; 17: 244-248

3 Brosens I, Gordts S, Habiba $M$ et al. Uterine cystic adenomyosis: a disease of younger women. J Pediatr Adolesc Gynecol 2015; 28: 420-426

4 Brosens I, Derwig I, Brosens J et al. The enigmatic uterine junctional zone: the missing link between reproductive disorders and major obstetrical disorders? Hum Reprod 2010; 25: 569-574

5 Brosens IA, Robertson WB, Dixon HG. The role of the spiral arteries in the pathogenesis of preeclampsia. Obstet Gynecol Annu 1972; 1: 177191

6 Milne F, Redman C, Walker J et al. The pre-eclampsia community guideline (PRECOG): how to screen for and detect onset of pre-eclampsia in the community. BMJ 2005; 330: 576-580

7 Steegers EA, von Dadelszen P, Duvekot JJ et al. Pre-eclampsia. Lancet 2010; 376: 631-644

8 Nakimuli A, Chazara O, Byamugisha J et al. Pregnancy, parturition and preeclampsia in women of African ancestry. Am J Obstet Gynecol 2014; 210: $510-520$

9 Novellas S, Chassang M, Delotte J et al. MRI characteristics of the uterine junctional zone: from normal to the diagnosis of adenomyosis. Am J Roentgenol 2011; 196: 1206-1213

10 Willms AB, Brown ED, Kettritz UI et al. Anatomic changes in the pelvis after uncomplicated vaginal delivery: evaluation with serial MR imaging. Radiology 1995; 195: 91-94

11 Tamai K, Koyama T, Umeoka S et al. Spectrum of MR features in adenomyosis. Best Pract Res Clin Obstet Gynaecol 2006; 20: 583-602

12 Dueholm M, Lundorf E, Hansen ES et al. Magnetic resonance imaging and transvaginal ultrasonography for the diagnosis of adenomyosis. Fertil Steril 2001; 76: 588-594

13 Hricak H, Alpers C, Crooks LE et al. Magnetic resonance imaging of the female pelvis: initial experience. Am J Roentgenol 1983; 141: 11191128

14 Leyendecker G. Redefining endometriosis: endometriosis is an entity with extreme pleiomorphism. Hum Reprod 2000; 15: 4-7

15 Lyall F. Priming and remodelling of human placental bed spiral arteries during pregnancy-a review. Placenta 2005; 26: 31-36 
16 Brosens JJ, Pijnenborg R, Brosens I. The myometrial junctional zone spiral arteries in normal and abnormal pregnancies. Am J Obstet Gynecol 2002; 187: 1416-1423

17 Pijnenborg R, Bland JM, Robertson WB et al. Uteroplacental arterial changes related to interstitial trophoblast migration in early human pregnancy. Placenta 1983; 4: 397-413

18 Brosens I, Pijnenborg R, Vercruysse L et al. The "Great Obstetrical Syndromes" are associated with disorders of deep placentation. Am J Obstet Gynecol 2011; 204: 193-201

19 Brosens I, Pijnenborg R, Benagiano G. Defective myometrial spiral artery remodelling as a cause of major obstetrical syndromes in endometriosis and adenomyosis. Placenta 2013; 34: 100-105

20 Redman CW, Sargent IL. Immunology of pre-eclampsia. Am J Reprod Immunol 2010; 63: 534-543
21 Raymond D, Peterson E. A critical review of early-onset and late-onset preeclampsia. Obstet Gynecol Surv 2011; 66: 497-506

22 Lisonkova S, Joseph KS. Incidence of preeclampsia: risk factors and outcomes associated with early- versus late-onset disease. Am J Obstet Gynecol 2013; 209: 544

23 Fisher SJ. Why is placentation abnormal in preeclampsia? Am J Obstet Gynecol 2015; 213: 115-122

24 Mochimaru A, Aoki S, Oba MS et al. Adverse pregnancy outcomes associated with adenomyosis with uterine enlargement. J Obstet Gynaecol Res 2015; 41: 529-533

25 Myatt L, Roberts JM. Preeclampsia: syndrome or disease? Curr Hypertens Rep 2015; 17: 83

26 Yorifuji T, Makino S, Yamamoto Y et al. Time spatial labeling inversion pulse magnetic resonance angiography in pregnancy with adenomyosis. J Obstet Gynaecol Res 2013; 39: 1480-1483 